\section{Memorial to Sir Walter Morley Fletcher}

THE public life of Great Britain suffered a loss of more than common magnitude through the death of Sir Walter Morley Fletcher, first secretary of the Medical Research Council, on June 7, 1933. He was then in his sixtieth year and in the height of those powers which he had used without stint in the advancement of knowledge for the relief of human suffering. Walter Fletcher gave richly to the common weal, and it is fitting that some worthy tribute of an enduring kind should be paid to his memory. An appeal has therefore been issued over the signatures of the Lord President of the Council, the president of the Royal Society and representatives of aspects of science and medicine with which Sir Walter Fletcher was particularly associated. It is considered that the tribute should consist in the first place of a personal memorial, and secondly of the inception of some scheme for the furtherance of the cause which Sir Walter Fletcher had so much at heart. It is therefore proposed first to commission a portrait bust, to be placed in a suitable setting in the entrance hall of the National Institute for Medical Research, at Hampstead. The remainder of the sum collected will then be used as a fund for building - at the farm premises of the National Institute at Mill Hill-a Walter Fletcher Laboratory, to be devoted particularly to those nutritional studies in which he was so keenly interested. This will not only provide an appropriate memorial, but also it will make an urgently needed contribution to the national equipment for work in what is at present among the most important of all branches of medical research. All subscriptions should be sent to the Secretary, Fletcher Memorial Fund, 38 old Queen Street, Westminster, S.W.1.

\section{Telford Centenary Exhibition}

Thomas Texford, the distinguished civil engineer, died at his house at 24 Abingdon Street, Westminster, on September 2, 1834, at the age of seventy-seven years, and a few days later was buried in the nave of Westminster Abbey. For the last thirteen years of his life he was president of the Institution of Civil Engineers, and in connexion with the centenary of his death the Institution has arranged an exhibition which was open for inspection at the conversazione this week and will remain open each day at 10 A.M.5 P.M. until June 22. The materials for the exhibition have been gathered together mainly through the efforts of Sir Alexander Gibb, whose forbears were associated with Telford in some of his works. Telford's whole life was devoted to engineering works of national importance, and his steady rise from a stone mason, working on Somerset House, to the head of his profession, was due to his wide knowledge, energy and sound judgment. He constructed many hundreds of miles of roads, more than a thousand bridges, some of the most important canals in Great Britain and also did valuable work on harbours. His most famous works included the Ellesmere Canal with the great Pont Cysylltau Aqueduct, the wrought iron suspension bridge over the Menai Straits and St.
Katherine's Docks. He took the liveliest interest in the formation and growth of the Institution of Civil Engineers, presenting to it a collection of books for the formation of a library and bequeathing to it several thousands of pounds. The exhibits collected for the occasion of his centenary relate to nearly all his activities and include plans, drawings, reports, note books, letters, portraits, etc. A carefully annotated catalogue has been prepared which itself forms a valuable addition to the material relating to the great engineer.

\section{History of Derbyshire Industries}

The Newcomen Society held its summer meeting in Derbyshire on June 6-9, and the members were able to pay visits to many interesting works. These included the Old Crown Derby China Works, the quarries of the Clay Cross Lime Co., the hosiery works of Messrs. George Brettle and Co., Ltd. and the Mill Close Lead Mine, Darley Dale. At various places, some interesting machines and engines were inspected and at the works of the D.P. Battery Co. two very fine water wheels were seen. After the Society's dinner on June 7, two papers were read, one on the High Peak Railway, and the other on the history of some Derbyshire industries. The latter was by Mr. Rhys Jenkins, who gave in it brief reviews of the lead, iron and other industries from the earliest records. Lead mining and smelting was carried on in Derbyshire by the Romans, and a number of pigs of lead with Latin inscriptions have been found. It is stated that there are no fewer than 4,000 disused lead mines in the county, and that some seventy years ago the output was 4,000 tons per annum. The lead smelting works near Lea appear to be the last in the county. Definite evidence of iron working go back to the twelfth century, and Mr. Jenkins traced the development from that time onwards. One interesting feature was the records of distinct industries in various localities, chains being made in one place, sickles and scythes in another, and so on. About a century and a half ago, there was a flourishing industry at Hartshorn, when hundreds of gross of wood screws were made weekly. Of Lombe's famous silk mill erected two centuries ago, nothing now remains; but its erection was an outstanding event in the history of machine building.

\section{High Speed Precision Photography}

As interesting demonstration was given on June 12 of a new development in the taking and timing of serial photographs of objects moving at high speed. The apparatus, which is easily portable, is the combined work of the Western Electric Co. and Kodak Limited. It was demonstrated that 2,500 exposures per second could be made of objects in normal daylight or illuminated with ordinary ' $\frac{1}{2}$-watt' type lamps on the standard small size Kodak film. The interest in the camera lies in its extreme simplicity. As the film has to move across the focal plane with speeds up to 50 feet per second, the usual intermittent motion must be dispensed with and a uniform motion substituted. Mounted between the lens (Kodak 